\title{
The Influence of Implementation of Human Resources Management towards the Success Rate of Management of Early Childhood Education Institutions in Sumedang Regency
}

\author{
Ipong Dekawati \\ Postgraduate Program of Management Education \\ Universitas Wiralodra \\ Indramayu, Indonesia \\ ipongdekawati@gmail.com
}

\author{
Dadang Suhendar \\ Postgraduate Program of Management Education \\ Universitas Wiralodra \\ Indramayu, Indonesia
}

\begin{abstract}
This study aims to identify and obtain an overview of the implementation of human resource management influence towards the success rate of management of early childhood education institutions in Sumedang regency. The method used is descriptive and verification methods, techniques of data collection used are questionnaire to 210 teachers in Sumedang. This study uses regression analysis techniques. The results of this study are the implementation of human resources management influences the success rate of management of early childhood education institutions in Sumedang regency. This study is expected to be useful in managing education in Sumedang, especially at the level of early childhood education. For the supervisor of a kindergartens as an input to make decisions regarding managing the human resources. Another benefit of this study, it can be used as the basis for the Department of Education in directing the head of early childhood education institutions in order to develop and improve the quality.
\end{abstract}

Keywords-Human Resource Management; Management of Early Childhood Education Institutions.

\section{INTRODUCTION}

Before prior education experts from western peninsula suggest long life education, Islam had already buzzed the concept of lifelong education. Almost fifteen centuries ago, the Prophet Muhammad have conveyed the concept of Islam related to lifelong education, namely through the famous hadith that "education starts from the cradle to the grave." Which means, human life is to learn, because from birth to death the opportunities for learning remain open.

Furthermore, interpreted, developed and implemented through phases of phasing in accordance with the person's ability taxonomy to receive transfer knowledge from their educators. In Indonesia, the phasing of education consists of: early childhood education, elementary education, secondary education and higher education. In the first chapter of Indonesian Law No 20 Year 2003 about National Education System is written, "Qualification is a stage of education which is defined by the level of development of learners, objectives to be achieved, and capabilities that are developed."
Each stage of education is very important in accordance with the growth and development of learners. By not mean to understate the meaning of higher education, early childhood education is very potential to be noticed. Because, in addition to an initial phase for learners recognize neither informal education both in the family environment or nonformal form of group play even in the form of formal education in kindergarten and Raudatul Athfal (RA). The early childhood education is an important moment for learners in shaping the character and prepare for the next level of education. Early childhood education is a development effort that aimed at children from birth up to the age of six years, which are accomplished by providing educational stimulus to help the growth and development of children physically and mentally in order to have the readiness to enter further education.

Kindergarten or Raudatul Athfal is the formal early childhood education institution. As an educational institution must be managed properly. Early childhood education institutions have a great responsibility as the foundation of resistance and progress of the nation. Anticipatory resilience against foreign cultures and separatist tendencies. Through a good start of education, building philosophical constancy of nation becomes more internalized (ingrained). The foundations of the nation's progress in terms of its readiness to follow the development of science and technology. Managed properly, meaning education management must be implemented and developed starting from early childhood education. Education management according to its function is starting from planning, organizing, directing, moving, controlling and evaluating should be implemented well. The goodness of the implementation of the management function will appear on the success rate of the program, including output and outcome.

From results of the overview of some Early Childhood Education Institutions and information from educators that the institution of early childhood education is not being managed as expected which seen from: location of activities, educators, learners, frequency of activities, parents role in paying dues, participation of parents in support the program, the number of groups of students, the source of funding, and 
support elements of supervisor which possibly happened because human resource management has not implemented properly. This study aims to determine how much influence of the implementation of human resource management towards the success rate of management of early childhood education institutions in Sumedang regency.

God created human beings as a perfect being. Perfection that is marked by its senses and intellect. Everything that is captured by the senses then turns into knowledge for themselves, which is then processed by the mind to be developed. Knowledge that can change attitudes and behavior increases to education. Therefore, education is a life-changing experience of knowledge, attitudes and skills of humans.

Referring to Indonesian Law No 20 year 2003 about National Education System, "education is a conscious and deliberate effort to create an atmosphere of learning and the learning process so that learners are actively developing the potential for him to have the spiritual power of religion, selfcontrol, personality, intelligence, character noble, as well as the skills he needed, society, nation and country. National education is education that is based on Pancasila and the Constitution of the Republic of Indonesia Year 1945 which is rooted in religious values, national culture of Indonesia and responsive to the changing demands of the times. The national education system is the overall educational components, which are interlinked in an integrated manner to achieve national education goals. "

If the education contemplated by the legislation can be interpreted that education is a process, education is also a system, within the education system is loaded with human resources with a high intellect. Along with the rapid progress of science and technology education continues to evolve (dynamic) which is of course must be efficient and effective in their operation. Therefore, education must be managed properly or should implement a proper management. Management is synonymous with management in a broad sense; the management means coordinating human efforts so that individual goals embodied in social result. [1]

Engkoswara and Aan Komariah put forward more detailed about management. According to them "management is a continuous process which is charged capabilities and special skills possessed by a person to perform an activity either individually or with others or through another person in coordinating and using all resources to achieve organization goals productively and efficiently. [2]

As the field of science, education also has a meaning of its own management. "Management education is a field of study and practice associated with the operation of educational organizations". [3] Management education can also be interpreted as activity, Pidarta stated that management education is "activity that combines educational resources to be concentrated in order to achieve educational goals predetermined". [4] Tilaar [5] emphasizes that management education is contained in planning, namely that "management education is an activity which implies the existence of planning or education plans and implementation activities".

Management education also requires the existence of quality results in the achievement of its objectives as stated by Engkoswara and Aan Komariah that management education is "an arrangement of cultivated fields of education conducted through the activities of planning, organizing, staffing, training, coordinating, communicating, motivating, budgeting, controlling, monitoring, assessment and reporting automatically to achieve the goal of quality education.

Management education consists of other management, which can be regarded as the sub-system management of education operational, for example: human resource management, infrastructure management, management of learners, and so forth. Human resource management is "a process of acquiring (recruitment), train, assess, and provide compensation to employees, noting their employment, health, security and justice issues". [6] 'Personnel administration is the art of enquiring, developing, and maintaining a competent work force in such a manner as to accomplish with maximum efficiency and economy the function and objectives of the organization'. [7]

Human resource management education has a realm to manage teachers and educators with specific activities that include functions: Planning. Define goals and standards; create rules and procedures; develop plans and forecasting. Organizing. Giving a specific task to each subordinate; create divisions; delegate authority to subordinates; making lines of authority and communication; coordinates the work of subordinates. Staffing. Determining the type of person who should be hired; recruit prospective employees; selecting employees; establish standard of performance; provide compensation to employees; evaluate achievements; provide counseling to employees; train and develop employees. Leadership. Encouraging others to complete the work; maintaining morale; motivate subordinates. Control. Set standards such as sales quotas, quality standards, or the level of production; check to see how the achievement compared with these standards; make corrections if needed.

The Ministry of Education through the Directorate General of Early Childhood Education, Non-Formal and Informal has issued Technical Guidelines for the Implementation of Early Childhood Education. On the Technical Guidelines there are indicators to assess the success of the program. Those indicators include: location of activities, educators, learners, frequency of activities, parent's role in paying dues, participation of parents in support the program, the number of groups of students, the source of funding, and support elements of supervisor. The success of the program in this study analogous to the successful management of the program. Therefore, to measure the success rate of early childhood education management in this study using these indicators. 


\section{METHODOLOGY}

Based on the level of explanation and the field of study, the type of this study is descriptive and verification. The method used in this study is survey explanatory. Independent variable in this study is the implementation of human resources while the dependent variable is the rate of successful management of Early Childhood Education Institutions This study selects the object on the unit for early childhood education institution in Sumedang. The population is all active educators in early childhood education institutions, which are 2060 teachers. Assuming that the views of the profession all the teachers got the same chance to be sampled. Therefore, the sampling method is simple random sampling. The number of samples taken refers to the opinion of Arikunto [8] who suggested that if the population of 100, then all of them are taken. Meanwhile, if the subjects are a lot, the sample can be taken as many as $10-15 \%$ or $20-$ $25 \%$ of the population. Based on Arikunto opinion, the samples taken are $10 \%$ or 206 respondents with cluster random sampling technique. The author uses data collection techniques as follows: The study of literature, documentation and questionnaires. The data were processed and analyzed using descriptive analysis and verification. Verification analysis technique used is the correlation analysis, coefficient of determination, Regression Analysis and Significance.

\section{RESULTS AND DISCUSSION}

Based on the results of the study that has been done, the result of the teacher feedback on the implementation of Human Resources Management, which can be seen in the following table.

TABLE I. IMPLEMENTATION OF HUMAN RESOURCE MANAGEMENT AT THE EARLY CHILDHOOD EDUCATION INSTITUTE OF (ECD) OF SUMEDANG

\begin{tabular}{ccc}
\hline Dimensions & Average Answer & Condition \\
\hline Employee Regulations & 3.37 & Fair Condition \\
Recruitment & 3.60 & Fair Condition \\
Job Description & 3.62 & Fair Condition \\
Supervision & 3.50 & Fair Condition \\
\hline
\end{tabular}

In Table 1 it can be seen that the lowest value in the implementation of human resources management at the Early Childhood Education Institute (ECD) of Sumedang is about employment regulations. This indicates that employment regulations are less well implemented because the employee code of conduct or rules in writing are rarely made. The highest dimension value is the job description because the average employees of Early Childhood Education Institutions (ECD) in Sumedang Regency are understood their duties and responsibilities.
TABLE II. SuCCESS RATE OF MANAGEMENT OF EARLY CHILDHOOD EDUCATION INSTITUTIONAL IN SUMEDANG

\begin{tabular}{ccc}
\hline Dimensions & Average Answer & Condition \\
\hline Location of activities & 3.31 & Fair Condition \\
The amount of educators & 4.00 & Good Condition \\
Learners & 4.06 & Good Condition \\
Numbers of group & 4.07 & Good Condition \\
Contest events & 4.30 & Good Condition \\
Participation of parents & 3.56 & Fair Condition \\
Support & 4.01 & Good Condition \\
\hline
\end{tabular}

In Table 2 almost all dimensions of Success Rate of Management of Early Childhood Education Institutional in Sumedang is already in good condition. However, the lowest value can be seen on the dimensions of the location of activities and participation of parents. Locations of activities considered poorly because there are many Early Childhood Education Institutions which the size does not meet the standard and condition of the building, the courtyard playground, furniture and color is still considered less attractive. Parents' participation is also still in a condition that is not so good because of the participation of financial terms, especially the monthly fees they paid are a little late sometimes. The biggest scores obtained by the dimensions of contest events, this indicates that in Sumedang there are many events held related to the contest for early childhood and the departments are actively participating.

\section{TABLE III. CALCULATION RESULTS OF CORRELATION}

ANALYSIS

Model Summary

\begin{tabular}{|c|c|c|c|c|}
\hline \multicolumn{5}{|c|}{ Model Summary } \\
\hline Model & $\mathrm{R}$ & R Square & $\begin{array}{l}\text { Adjusted R } \\
\text { Square }\end{array}$ & $\begin{array}{l}\text { Std. Error of the } \\
\text { Estimate }\end{array}$ \\
\hline 1 & $.626^{\mathrm{a}}$ & .392 & .389 & 3.921 \\
\hline
\end{tabular}

Implementation_human_resources_management_X

The results of the correlation calculations can be seen in Table 3. Pearson correlation value is 0626; this value indicates that the correlation of implementation of human resource management and the Success Rate of Management of Early Childhood Education Institutional is strong. The coefficient of determination is equal to $39.2 \%$, means that the success rate of management of Early Childhood Education Institutions (ECD) 39.2\% are influenced by the implementation of human resource management. The remaining $60.8 \%$ is influence by other variables, which are not examined in this study.

TABLE IV. CALCULATION RESUlTS OF REGRESSION ANALYSIS

Coefficients

\begin{tabular}{|c|c|c|c|c|c|c|}
\hline \multirow{2}{*}{\multicolumn{2}{|c|}{ Model }} & \multicolumn{2}{|c|}{$\begin{array}{l}\text { Unstandardized } \\
\text { Coefficients }\end{array}$} & \multirow{2}{*}{$\begin{array}{c}\text { Standardized } \\
\text { Coefficients } \\
\text { Beta }\end{array}$} & \multirow[b]{2}{*}{$\mathrm{t}$} & \multirow[b]{2}{*}{ Sig. } \\
\hline & & B & $\begin{array}{l}\text { Std. } \\
\text { Error }\end{array}$ & & & \\
\hline \multirow[t]{2}{*}{1} & (Constant) & 51.934 & 1.660 & & 31.291 & .000 \\
\hline & $\begin{array}{l}\text { Implementation_- } \\
\text { HRD Management }\end{array}$ & .359 & .031 & .626 & 11.571 & .000 \\
\hline
\end{tabular}


The regression equation obtained in Table 4 is $\mathrm{y}=51934$ $+0359 \mathrm{X}$. This equation can be interpreted that if the implementation of human resources increased 1 point, then the rate of success rate of management of early childhood institutions increased by 0359 . The significance value obtained through the significance test is less than 0.05 so that the influence of the implementation of human resource management to success rate of management of Early Childhood Education Institutions in Sumedang, West Java province of Indonesia is significant.

\section{CONCLUSION}

The results from this study are that the implementation of human resource management can affect the success rate of management of Early Childhood Education Institutions (ECD). Therefore, Early Childhood Education Institutions (ECD) needs to improve the implementation of human resource management, which the condition of each dimension is still not so good. The top priority needs to be improved is employment regulations by making the rules in writing, then socialized and agreed by all employees. Supervision also needs to be improved, including the recruitment process and the clarity of the job description.

\section{REFERENCES}

[1] Koontz, Harold, O'Donnell, Cyril and Weihrich, Heinz, Manajemen, 1st Edition, Jakarta: Erlangga, 1994.

[2] Engkoswara, and Komariah, Aan, Administrasi Pendidikan. Bandung: Alfabeta, 2010.

[3] Bush, Tony, Theories of Educational Leadership and Management, London: Sage Publications, 2003.

[4] Pidarta, Made, Manajemen Pendidikan Indonesia. Jakarta: Rineka Cipta, 1988

[5] Tilaar, H.A.R., Manajemen Pendidikan Nasional, Bandung: Rosda Karya, 1999.

[6] Dessler, Gary, Manajemen Sumber Daya Manusia, Jakarta: PT. Indeks, 2010.

[7] Musanef, Manajemen Kepegawaian Republik Indonesia, Jakarta: CV. Haji Masagung, 1991.

[8] Arikunto, Suharsimi, Prosedur Penelitian Suatu Praktek, Surabaya: Bina Aksara. 1989. 